\title{
North Sea Investigations.
}

\author{
By
}

J. T. Cunningham, M.A.

I. Statistics of Small Fish landed at Grimsby .
II. Notes on the General Course of the Fishing.
III. Observations on the Natural History of Plaice
IV. On the Relations of the Generative Organs, and of the Sexes, in some Fishes
V. Two Trips to the Eastern Grounds

IN accordance with instructions from the Council of the Association, I arrived in Cleethorpes on February 4th last, and proceeded to make investigations into the biological questions presented by the fisheries in the North Sea. A large portion of my time was, however, absorbed by the work of preparing a summary of our knowledge of the natural history of marketable marine fishes, for publication in book form, and consequently the observations to be here recorded are not so extensive nor so complete as I should have otherwise been able to make them. It must also be noted that they are confined to a period of only three months-from the beginning of February to the end of April. The work has consisted only of observations in the fish market at Grimsby Docks, and of the examination of fish there procured in the Cleethorpes Hatchery; I have not been able to make any voyages on fishing boats. I have received from Mr. Holt, my predecessor at this post, all the assistance that information concerning persons and circumstances could afford me, and I have had the valuable services of Mr. Clark, the caretaker of the Hatchery.

\section{Statistics of Small Fish Landed at Grimsby.}

The statistics to be here recorded are in continuation of those published in preceding numbers of the journal by Mr. Holt. My responsibility for them consists only in the addition of the figures, and the comparisons made. The counting of the boxes in the market has 
been entirely the work of Mr. Clark, who has continued to follow the method arranged between himself and Mr. Holt. As far as I am able to judge, the results are very reliable.

Plaice.-During the seven months covered by the figures, no Iceland fish have been landed, and I understand that it is uncertain whether any vessels will visit the Iceland grounds this summer.

\begin{tabular}{|c|c|c|c|c|c|c|}
\hline \multirow{4}{*}{1894.} & Month. & Total boxes. & & Large. & & Small. \\
\hline & October & 13,300 & ... & 13,087 & $\ldots$ & 213 \\
\hline & November & 20,835 & $\ldots$ & 20,607 & $\ldots$ & 228 \\
\hline & December & . 13,640 & ... & 13,637 & $\ldots$ & \\
\hline \multirow[t]{4}{*}{1895.} & January & 5,764 & $\ldots$ & 5,764 & $\ldots$ & \\
\hline & February & 6,937 & $\cdots$ & 6,937 & $\cdots$ & \\
\hline & March & 9,180 & $\ldots$ & 8,083 & $\ldots$ & 1,097 \\
\hline & April & 11,614 & $\ldots$ & 10,931 & $\ldots$ & 683 \\
\hline
\end{tabular}

In March, 13 boxes of the small were from the Humber; in April, 25; the rest being from the east side of the North Sea. In April, 200 of the boxes from the eastern grounds were landed by German steam trawlers, and 16 boxes by cargo steamer, leaving only 442 boxes landed by English trawlers. If these figures are compared with those of the corresponding months in 1893-94, as given on p. 170, vol. iii. of this Journal, it will be seen that there is a considerable falling off in the quantity of small plaice landed, and an increase in the quantity of large. Except October, the total of large plaice for every month is larger, and that of small plaice is smaller for every month, without exception. The totals of the seven months taken together are:

In 1893-94, 51,654 boxes of large, 10,042 small.

In $1894-95,79,046 \quad$ " " " 2,224 ,

I am unable to give a reason for this. In the earlier period there was only one month of the seven, namely, April, in which any of the vessels were fishing at Iceland, but there may have been diversion of fishing power to other regions. Whether the increased supply of large plaice is due to greater abundance of fish, better weather, or more vsseels, is entirely beyond my knowledge. In the statistics of the earlier period, however, there were eighteen days omitted, and this alone may be sufficient to account for the difference in the figures of large plaice, while it makes all the more striking the difference in the quantity of small. An apparent scarcity of small plaice on the eastern grounds will be mentioned below.

Haddock.-The numbers of boxes of small haddock landed monthly are as follows: 


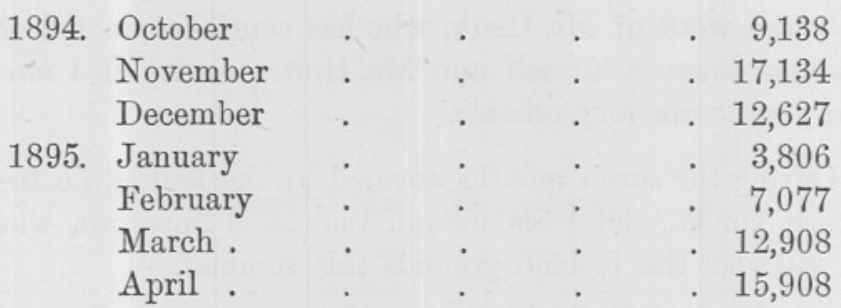

Comparison of these figures with those given by Mr. Holt on p. 174 of vol. iii. shows a very great increase, except in January, for which the total is smaller. There is no indication, so far as I know, that the supply of large haddock has fallen off.

Cod.-The following are the monthly totals of boxes of trawled codling :

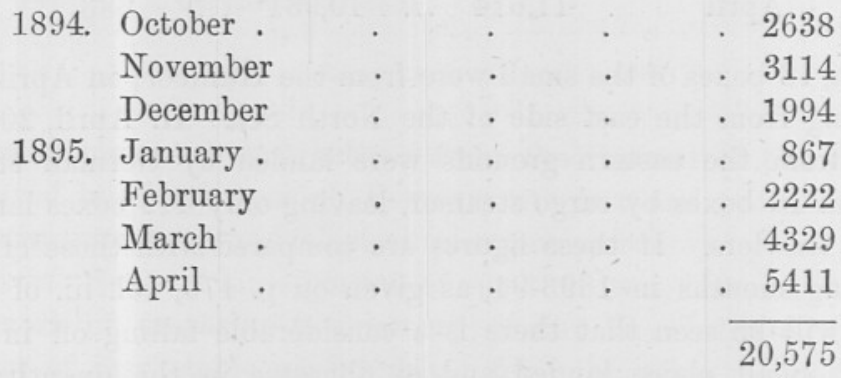

The total for the corresponding months of the previous year was 17,319 ; but the figures for nineteen days were not obtained, so that the difference does not appear to be really very great.

\section{Notes on the General Course of the Fishing.}

In the latter half of February, a large number of steam trawlers were fishing in the neighbourhood of Flamborough Head, where the coast is steep, the 20 fathom line being only four or five miles from the coast, and the soundings descending to 35 fathoms. The principal item of the catch on this ground was large cod, which were taken in large numbers in spawning condition. This region is, in fact, a spawning ground for cod, and I am informed by the fishermen that it is worked for cod regularly every year at this season. The proportion of codling was not great; for instance, in one voyage of a steam trawler, lasting nine days, there were 90 score of cod, and only 4 boxes of codling. There were also caught 10 to 12 boxes of large plaice, a few boxes of haddock (about 20), a few turbot, mostly large, about 1 box of soles, 1 or 2 of lemon soles, and a few boxes of whiting. 
Other steam trawlers, but not many, were fishing on the Great Fisher Bank, at depths of 35 to 50 fathoms. The chief item in their takes was haddock, some vessels bringing in 200 to 300 boxes of large haddock, and 6 to 27 boxes of small. They also got usually about 8 to 10 boxes of large plaice, 5 or 6 boxes of witches (Pleuronectes cynoglossus), a few large turbot, a few halibut, rarely a brill, skate, roker, cat-fishes, and "monks" (Lophius piscatorius).

Some of the smaller steam trawlers, and some sailing smacks, were fishing the Great Silver Pit, on the south edge of the Dogger Bank, and here, as usual in cold winters, considerable numbers of soles were taken, 10 boxes down to 2 or 3 being the usual quantity. Usually I only saw $2 \frac{1}{2}$ or 3 boxes of soles landed by a sailing smack, and 5 to 7 by a steamer; but once I saw 10 boxes from a single smack. On this ground haddocks were taken in moderate numbers, also a few boxes of plaice, whiting, dabs, some cod and codling, and ling; turbot were rather plentiful, brill less so.

Others of the smaller steamers fished within a radius of 50 miles from Spurn Head to the east and south-east. These brought in mixed catches-sometimes a number of turbot and brill, a few soles, haddock, plaice, cod, roker, and skate. These grounds appear to be fished more or less regulariy all the year round.

The first voyage of small plaice from the Eastern Grounds was landed on March 20th. There were 246 boxes of the small, 29 somewhat larger, and also 4 brill and 1 turbot; but no other fish. They were taken on the Sylt Ground, at 13 to 17 fathoms, south of the Outer Horn Reef Lightship. These fish fetched 11s. to $12 \mathrm{~s}$. per box, the larger 18s., while on March 15th the ordinary large plaice sold for $34 \mathrm{~s}$. 6 d. per box. Another voyage of 230 boxes was landed on March 21st, also from the Sylt rough ground, and another on March 25th, consisting of 150 boxes, from the same neighbourhood. In this last voyage there was a box of small turbot, containing 90 to 100 fish, mostly about 1 foot in length.

In the latter part of March, many steam trawlers were fishing the grounds south of the Dogger Bank, namely, Well Bank, and a place called Markham's Hole, which is 80 miles east of Spurn Head. These grounds are on the south side of the valley called the Silver Pit, and are from 15 to 20 fathoms deep; but the Hole, so far as I can judge, is one of the depressions which descend to 40 fathoms. The catches were mixed, consisting of about 50 to 70 boxes of haddock, about 70 cod, a few boxes of plaice, some soles, lemon soles, and whiting, and a few brill and turbot.

In April, although occasional catches were brought in from the Flamborough Head ground, and from the Great Fisher Bank, a number 
of vessels were fishing on the Dogger, where, so far as I could learn, fish were very scarce in the winter months. Here, as well as on neighbouring grounds, small plaice were in excess of the large, and formed a few separate boxes; the condition of these small plaice is discussed below. Haddock and plaice formed the main part of the catch. It has been explained in Mr. Holt's papers that haddock are packed for sale on the pontoon in three sizes-the largest, called gibbers, from the mode in which they are gutted; the medium, called kit, because conveyed in kits to the curing houses; and the small. From the Dogger Bank, a week's voyage produced about 30 to 40 boxes of the gibbers, about 60 upwards of kit, and 30 to 50 small. The largest catch I saw from a steam trawler was landed on April 25th, from one week's fishing, and consisted of 6 boxes plaice, 150 boxes kit, 80 boxes gibbers, $3 \frac{1}{2}$ boxes small haddock, 1 score of turbot, and $\frac{1}{2}$ score cod. This catch realised $£ 130$, which is considerably more than the average value of a week's catch.

I have already mentioned three voyages of small plaice, landed March 20th, 21st, and 25th. The small number landed altogether in March and April offers a remarkable contrast to the condition of things in the same months in 1894. On March 26th there was landed a voyage of 260 boxes, the result of three weeks' fishing south of the Horn Reef. On the 27th another voyage, this time of a fortnight's fishing, of 200 boxes was landed. It should be mentioned here that more than one vessel had tried the Sylt grounds for small plaice before March 20th, and had failed to catch any. The explanation offered to me by Mr. Alward, and also by several of the skippers of steam trawlers, was that the weather had been too cold; that the small plaice bury themselves in the sand in cold weather, and remain motionless, taking no food-hibernate, in fact-so that the trawl passes over them without disturbing them. It is certain that the small plaice in the tanks at the Cleethorpes Aquarium did behave in this manner, and emerged in a lively and hungry condition in the fine warm weather, at the very time that the small plaice were landed at the docks. On the 29th a sailing trawler landed 78 boxes. Voyages of small were landed on April 3rd, 4th, 8th, and 9th, but from this date until the 26th no catches were landed from the Eastern Grounds. It is true that cold easterly winds set in during the greater part of this time, and the weather was dull, and this change in the weather may have been the principal cause of the disappearance of the fish from the market. On the 26th, 30 boxes were landed by a German steam trawler; and on the 29th, 170 boxes from another German boat.

It seems to be the fact that on April 24th, large numbers of small plaice, from the Eastern Grounds, were landed by steam cutters at 
Billingsgate. A statement to that effect was made at the conference of the Protection Association, and I saw a considerable proportion of plaice, from $5 \frac{1}{4}$ inches upwards, among those landed at Billingsgate Market on May 3rd and 4th. But I am unable to say whether any were landed in London or other ports between the 9th and 24th, when they were absent at Grimsby.

\section{Observations on the Natural History of Plaice.}

In order to obtain a more exact and detailed knowledge of the habits and history of the fish on the North Sea fishing grounds, I have, as far as time and opportunity allowed, endeavoured to ascertain the condition with respect to feeding and breeding of the fish that were brought in from different grounds at successive times. The observations I have here to record are merely tentative and preliminary, but I think they are enough to show that the method is a necessary continuation and extension of those of a more general character which have already been applied with good results.

The first sample of plaice which I examined consisted of six specimens caught in the north-west part of the Great Fisher Bank at a depth of 35 to 39 fathoms. They were obtained in the market on February 13th. There were four females $17 \mathrm{in}$. to $21 \frac{3}{4} \mathrm{in}$. long. Three of these, $21 \frac{1}{4}$ in. to $21 \frac{3}{4}$ in., were approaching the spawning condition: the ovaries were much enlarged, the eggs full of yolk, but no ripe eggs present: they had not commenced to spawn. In the smallest female, $17 \mathrm{in}$, the roe of the right side was $3 \frac{1}{16} \mathrm{in}$. long, measuring from the anterior end of the ventral fin; the end of it $6 \frac{1}{4} \mathrm{in}$. from the posterior end of that fin. There were no yolked eggs in the ovary. Under the microscope all were transparent, but there were opaque granular masses, which I believe to be evidence that spawning has taken place. I have given in my paper on the "Ovaries of Fishes," in this Journal, vol. ii. p. 154 to 160 , some evidence that these masses are the disappearing remnants of partially developed yolked ova, which are always found in the spent ovary. This specimen of $17 \mathrm{in}$. would undoubtedly have been considered, according to the views hitherto accepted, as immature, but it seems to me it was probably a spent fish. It cannot be asserted as a certainty that these granular masses never occur in an immature ovary; to settle the doubt it will be necessary to make a careful examination of plaice in November and December, when all fish which are about to spawn will have a large amount of yolk in the eggs, and all fish in which the eggs are transparent and yolkless must be immature. In other words, at that season recently-spent fish will not exist, and then 
it will be possible to ascertain with certainty whether an immature ovary can contain these granular masses. In the meantime it is not certain that this fish, and others like it, are immature, and have not already spawned. The remaining two specimens, $16 \frac{1}{4}$ in. and $17 \frac{3}{4}$ in. long, were ripe males. This length, $16 \frac{1}{4}$ in., was about the smallest of these Fisher Bank plaice, and it follows that these were chiefly mature plaice in the breeding condition. The stomachs of all were empty, or very nearly so; in the intestines of some were a few crushed shells, the remains of previous meals.

On February 16th, I found that most of the fish landed was from the home grounds. There are at Grimsby a number of rather small steam trawlers, which never remain out more than a week, and confine their operations within a limit of about 100 miles from Spurn Light. I noticed that the greater number of the plaice landed were rather small, not forming separate boxes of "small," but each box containing a large number of small at the bottom, with a few large fish on the top. I examined a sample of the smaller. There were seven females, from $11 \frac{5}{8}$ in. to $14 \frac{5}{8} \mathrm{in}$. long. One $12 \frac{1}{2}$ in. was nearly ripe, a large number of the eggs already transparent, that is to say, almost ready to be shed. All the others had small ovaries, in appearance immature, but in all of them under the microscope the opaque granular masses were very conspicuous. Even the smallest fish, $11 \frac{5}{8}$ in. long, had the ovary in this condition. It seems probable that all these were spent fish. There were six males, the smallest $10 \frac{7}{8} \mathrm{in}$. long, the largest 16 in. This last was the only one ripe, in all the others the testis was very thin, and would, I suppose, have been put down by previous observers as immature, but in my opinion were more probably spent. I did not ascertain more particularly where these fish were caught.

On February 27th I saw the fish landed from a steamer which had been fishing off the Leman Shoal, at a depth of 12 to 17 fathoms. She had so many small plaice that they formed $7 \frac{1}{2}$ separate boxes, in addition to $35 \frac{1}{2}$ boxes of fish of the usual sizes. I bought a whole box of these small plaice, the price of which was $16 \mathrm{~s}$. $6 \mathrm{~d}$. The box contained 212 fish, the smallest a little over $7 \mathrm{in}$., the largest between 13 and $14 \mathrm{in}$. The small plaice from the Eastern Grounds, according to Mr. Holt, were about 300 to a box, the majority from 7 to 13 in. long. It is evident, therefore, that the plaice here considered are within the same limits of size as the eastern small, but apparently a little larger on the average. Examination showed that there were 186 males, and only 26 females. The condition of the males may be thus shown :- 


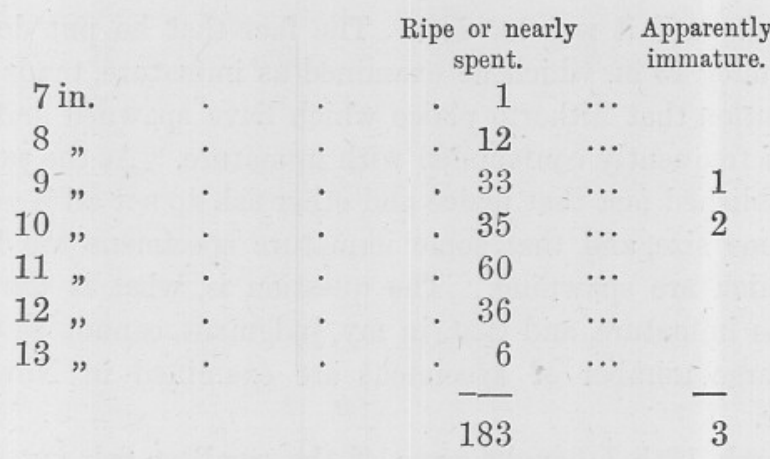

It is obvious that the three in the second column were not likely to be really different from the rest, and I have no doubt that they were really spent.

The condition of the females was:-

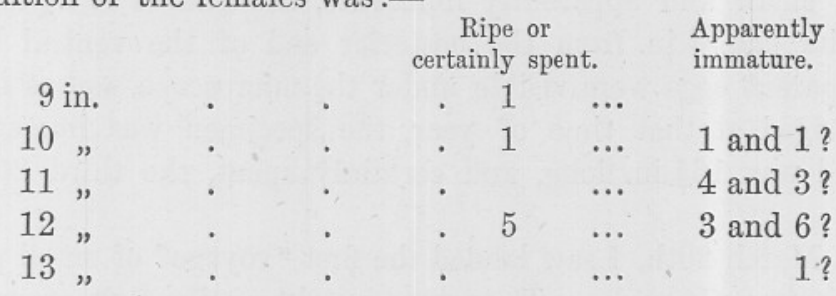

The smallest female was $9 \frac{1}{8}$ in. long, the right ovary $3 \frac{3}{8}$ in. long and flaccid, and this fish had certainly spawned, as there were some ripe eggs still in the cavity of the ovary. Eight of the specimens, 10 to 12 in. long, showed no signs of previous spawning, and were very possibly immature, but the others marked ? showed in abundance, and very distinctly, the opaque granular masses, which I believe to be evidence of previous spawning. One specimen, $11 \frac{1}{4} \mathrm{in}$. long, showed very numerous masses of granules: the end of its right ovary was $2 \frac{1}{8}$ in. from the anterior end of the ventral fin, and $3 \frac{3}{4}$ in. from the posterior end. I consider this fish to have been almost certainly spent. But putting aside all questions of probability, the examination of this sample proves that male plaice are sometimes ripe in the North Sea at $7 \mathrm{in}$, and females at $9 \mathrm{in}$. Mr. Holt found a ripe male at 6 in. (see his paper in this Journal vol. ii. p. 376), but regarded it as altogether exceptional, and found only a few nearly ripe at 9 and 10 in., none at 11 and 12 . He records one female as mature at $13 \mathrm{in}$., none at 14 , and many from $15 \mathrm{in}$. upwards. On the other hand, the condition of the sample considered agrees closely with the results I obtained at Plymouth, where I found a male and two females mature at 9 in. Mr. Holt states that he examined the larger fish chiefly during the spawning season, and I can only infer that he did not begin to examine

New Series,-Yol, IV. No. 1. 
smaller fish until it was too late. The fact that he put down all the females under $13 \mathrm{in}$. which he examined as immature, tends to support my contention that hitherto plaice which have spawned and recovered, have been frequently confounded with immature. At the same time, it is an established fact that plaice and other fish do not all begin to spawn at the same size, and that some immature specimens are larger than others which are spawning. The question is, what is the maximum size of the immature, and that, in my judgment, cannot be determined until a large number of specimens are examined in November and December.

On March 13th I bought some of the smallest fish out of a box of large plaice from the Great Fisher Bank, in order to further examine the condition of deep-water plaice. Of these, 6 were males from $14 \frac{3}{8}$ to $17 \frac{1}{4}$ in. long, all ripe. Only 3 were females; one was $12 \frac{1}{2} \mathrm{in}$. long, the ovary small and apparently immature, the end of it $2 \frac{3}{4}$ in. from the anterior end, $4 \mathrm{in}$. from the posterior end of the ventral fin. Only transparent eggs were visible under the microscope, and as far as could be judged at that time of year, the specimen was immature. The second was $16 \frac{5}{8}$ in. long, and certainly spent, the third $205 \frac{5}{8}$ in. long, ripe.

On March 20th, I saw landed the first "voyage" of small plaice from the Eastern Grounds. They were caught on the Sylt ground south of the Horn Reef Light, at a depth of 13 to 17 fathoms. There were 246 boxes of small, 29 of somewhat large fish, and the price was $11 \mathrm{~s}$. to $12 \mathrm{~s}$. a box for the small, 18s. for the larger. I examined a sample of the small: they were taken at random, without any selection, and were given to me by Mr. George Alward. The total number was 55, the sizes and sexes being as follows :-

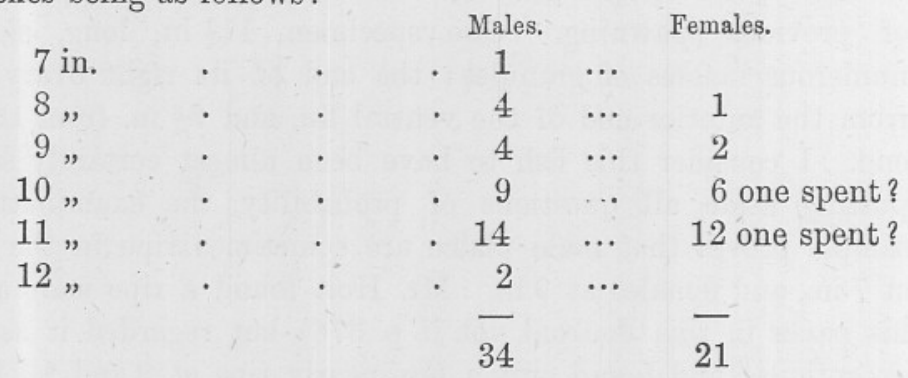

In all the males the testes were a mere thin band, and apparently immature. In none of the females was the spent condition found with certainty, the ovaries were all small, as in the immature, and under the microscope all the ova yolkless. But in nearly all granular masses were present in the germinal tissue, although these in most cases were very rare and small. In one specimen $10 \frac{7}{8} \mathrm{in}$. long, they were large and 
numerous, and had obviously the character of dead yolked eggs. In one $11 \frac{5}{8}$ in. long, no granular masses were seen.

Nearly all these fish were crammed with food only partially digested. In most cases this consisted of Lamellibranch remains, broken shells and flesh. In many of the stomachs there were a number of long white muscular masses 1 to $2 \mathrm{in}$. long. I identified these as the "feet" of Solen, having found them sometimes connected with shells and remains of the entire animal, but many stomachs were full of the muscular masses, with no shells in either stomach or intestine. It appears, therefore, that the plaice bites off the foot of the larger Solens without swallowing the whole animal; the entire Solens present were small. Less frequently there were present Polychaeta (usually Nereis sp.), crabs (Portunus sp. of small size), brittle-stars (Amphiura sp.), and in one case a Nemertean, apparently Carinella. Five of the fish contained nothing recognisable, of the other 50

$\begin{array}{llrl}\text { Lamellibranch occurred in } 42 ; 84 & \text { per cent } \\ \text { Solen } & " & 33 ; 66 & \\ \text { Polychaeta } & " & 17 ; 34 & \\ \text { Amphiura } & " & 5 ; & 10 \\ \text { Nemertean } & " & 1 ; 2 & \end{array}$

On the following day, March 21st, another voyage of small plaice was landed from the same ground, and I bought a sample. I had the smallest selected from four boxes, and the sizes and sexes were found to be as follows:

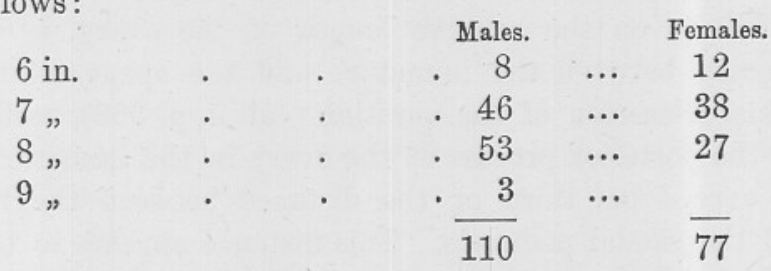

I examined the ovaries of two specimens-one $6 \frac{1}{2}$ in., one $7 \frac{3}{4}$ in.-and saw no trace of the granular masses. The food was the same as before.

On April 1st a steam trawler landed 10 boxes of large plaice, and 9 of smaller, caught on the western shoal of the Dogger Bank, at a depth of 9 fathoms. I bought a sample of the smaller: there were 19 of them in all. The results of examination were:

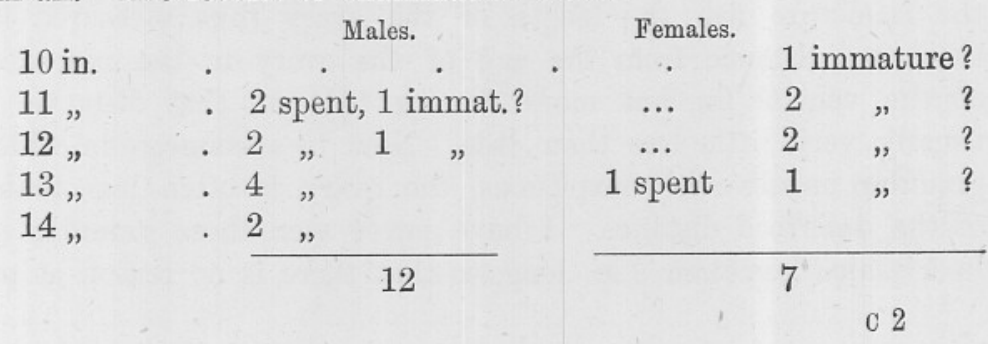


The spent female was $13 \frac{1}{2}$ in. long, the ovary $3 \frac{3}{16}$ and $4 \frac{1}{16}$ in. from the ends of the ventral fin. Under the microscope it showed no yolked eggs or opaque masses - apparently they had already been absorbedalthough the ovary had not lost its collapsed flaccid condition. Nearly all the other females, although otherwise not indicating the spent condition, showed more or less of the opaque granular masses in the substance of the ovary, and I have little doubt that all had spawned. The males also, I have no doubt, had spawned, the testes being somewhat larger and softer than in the immature.

These fish had been feeding, but were not so crammed as those from the Sylt grounds. In 10 the stomach was nearly empty, and the contents of the intestine much digested, though usually containing a few shells. Of the other 9 Lamellibranch remains were present in all, and consisted chiefly of Solen. One $13 \frac{1}{2}$ in. long had the stomach crammed with bits of white molluscs' flesh about $\frac{1}{2}$ in. long. These were the ends of the siphon tubes of some Lamellibranch, apparently not Solen. Polychaete worms occurred in 4.

On April 2nd I examined a few small plaice caught by the shrimp shove-net at Cleethorpes. Among them was a female $7 \frac{1}{8}$ in. long, the end of the right ovary $1 \frac{1}{2}, 2 \frac{1}{8}$ in., from the anterior and posterior ends of the ventral fin respectively, the eggs under the microscope without yolk and without any trace of granular masses. Another female was 7 in. long, likewise without any trace of granular masses. These fish were undoubtedly immature. I have found it quite impossible to rely with confidence on the relative length of the ovary, as a criterion to distinguish between the immature and the spent condition. Mr. Holt, in his discussion of the question (vol. ii. p. 368), states that the length of the posterior process of the ovary in the immature condition does not exceed one-third of the distance between the first hæmal spine and the caudal peduncle. This distance appears to be the same as that which I have used as the standard, namely, from the anterior to the posterior end of the ventral fin, but I am in doubt about the point from which the length of the posterior process was measured by Mr. Holt. To obtain a constant point of measurement, I have measured the length of the ovary in situ, from the front of the first ray of the ventral fin to the posterior extremity of the ovary. In the immature fish the length of the ovary thus measured is less than the distance from the end of the ovary to the posterior end of the ventral fin, but more than a half of that distance. It is usually very little less than $\frac{2}{3}$ rds. Now in specimens in which the granular masses are conspicuous, the ovary is often less than $\frac{2}{3}$ rds of the described distance. I have never seen these granular masses in a plaice less than $9 \mathrm{in}$. long, so that there is no reason at present 
to suppose that they ever occur in a specimen which has not spawned. In specimens in which the ovary, measured as I have described, is equal to, or greater than a half of the length of the ventral fin, there is no doubt that the fish is spent. So far, my conclusions agree entirely with Mr. Holt. But that observer has rejected the possibility that the spent ovary might go on diminishing until it was as small as in an immature fish, and he does not mention the granular masses at all. My contention is that not only are the granular masses evidence of previous spawning, but that they are rapidly absorbed, so that in a fish over $9 \mathrm{in}$. long, there may be, some time after it has spawned, no indication left to distinguish it from an immature fish, which has never spawned at all. I have reason to believe that this complete reversion of the ovary to the apparently immature condition occurs chiefly or only in the smaller, i.e., the younger fish, and does not take place to the same degree in fish which have spawned several times.

On April 15th, I saw thirty boxes of plaice landed from a vessel which had been fishing at Markham's Hole and the Swatchway, grounds to the S.E. of the Dogger Bank, and from twenty to twentyfive fathoms in depth. I bought a sample for examination. There were 23 fish in all-11 females, 12 males.

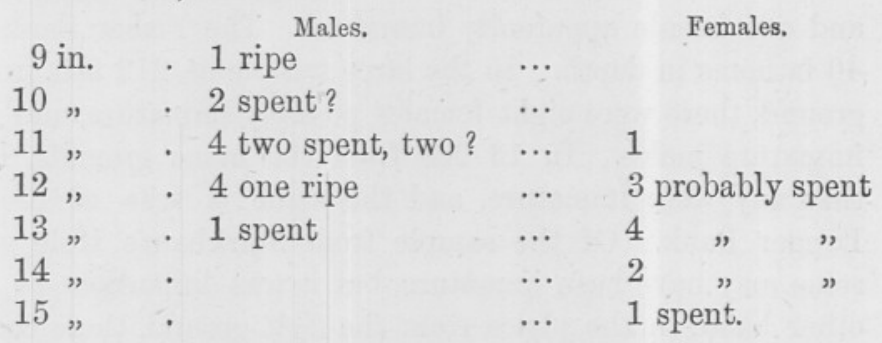

I could not be quite certain that any of these were really immature. Of the males four were doubtful, two at $10 \mathrm{in}$., two at 11 in., but I do not believe they were immature. Of the females, the one at $11 \mathrm{in.} \mathrm{had}$ no yolk and no granular masses, and may have been immature. Of the three females at 12 in., one showed no masses, the other two showed them very distinctly. Of the four at $13 \mathrm{in}$., one showed no masses. Of the two at $14 \mathrm{in}$., both showed the masses. The one at $15 \mathrm{in}$. showed the masses very distinctly, and was certainly spent. As usual the food was Solen and other molluscs, worms, and occasionally a small crustacean.

On May 3rd and 4th, I visited the Billingsgate Market, in London, where I was introduced to 'Mr. Johnson, the officer of the Fishmongers' Company, and from him received great courtesy and assistance in my enquiries. He informed me that about a third of the supply of fish received there is landed by steam cutters, who bring it from fleets of 
trawlers fishing in the North Sea, the rest coming by railway. It had been stated a few days before, at a conference of the National Sea Fisheries Protection Association, that great numbers of small plaice were being landed at Billingsgate. On the two mornings when I was there, the proportion of small fish was not so large as it had been, and I failed to obtain a box for complete examination. I saw, however, some of the fish landed from a "cutter," or carrier, and the smallest plaice I could see and measure was 6 in. long. This was one of a few lying about the deck, which had fallen from the boxes. I also examined 8 specimens brought to me by Mr. Johnson, of these only two were over 6 in., the rest were below that size, the smallest being $5 \frac{1}{4}$ in. I could not find out where these fish were caught, except that it was somewhere on the eastern side of the North Sea.

I think it will conduce to clearness and precision in considering the data I have given, to keep separate the questions of size and reproductive maturity. To dispose of the latter first, it seems of interest to me, whether it has a practical bearing or not, to try to discover whether immature plaice are found on all grounds, or to what depths and regions they are chiefly confined. I have described samples, 15 fish altogether, from the Great Fisher Bank, and among them were no immature males, and one female apparently immature. The Fisher Bank is from 20 to 40 fathoms in depth. In the large sample of 212 fish from the Leman ground, there were eight females possibly immature, and three possibly immature males. In 13 fish from the home grounds, I am not sure that any were immature, and the same is true of the 19 from the Dogger Bank. Of the sample from Markham's Hole on April 15th, some may have been immature, but it was difficult to be sure. On the other hand, in the plaice from the Sylt ground, there can be no doubt that a large proportion were immature, all females under 9 in. certainly, and a proportion of those above that size, although I am inclined to think, for the reasons given, that some had spawned. I have not examined many plaice from the Humber, but there can be no doubt that in the earlier months of the year nearly all of these are immature. As far as we can judge at present, it would appear that the year-old fish, all of which are immature, are not taken at the season of the year covered by the present observation, in any considerable numbers on any of the off-shore grounds. I consider that the small plaice from the Sylt grounds and from the Humber, consist largely, but not exclusively, in the case of the former, of year-old fish.

To consider now length only. The lower limit of plaice from the Fisher Bank was $12 \frac{1}{2}$ in. Of the small fish from the Leman ground, which is opposite the Lincolnshire and Norfolk coasts, the lower limit was 7 in. for males, $9 \mathrm{in}$. for females, and only one fish in a box of 
212 was under $8 \mathrm{in}$. Of the sample from the home grounds, there were no males under 10 in., no females under 11 in. Of fish from the Dogger Bank and grounds to the south of it, the lower limit was 9 in. for males and $10 \mathrm{in}$. for females. In the first sample from the Sylt ground, the minimum was $7 \mathrm{in}$., and there was only one fish out of 55 under $8 \mathrm{in}$. In the second sample, selected from 4 boxes, the minimum was 6 in., and there were 104 fish out of 187 under 8 in. At Billingsgate, a considerable number of the plaice landed were under 6 in. The upper limit is also of some importance, although it is not fully determined by these observations. Of the fish from the Sylt ground none were above $13 \mathrm{in.}$ in length; in the sample from the Leman ground the upper limit was 14 in., but there were plenty larger than this in the same eatch, and in all the other samples there were fish over 14 in.

It appears, therefore, that in the period covered by these observations, the usual minimum on the off-shore grounds is $9 \mathrm{in}$. for males, $10 \mathrm{in}$. for females, but occasionally it may be as low as 7 in. and $9 \mathrm{in}$. Fish below these limits have been obtained only from the Sylt ground and the Humber. Parts of the Dogger Bank are quite as shallow as the Sylt ground, where the small plaice are taken, yet such fish are not found there. Proximity to the land, therefore, appears to be an essential condition in the rearing of young plaice. But the question is, why are the small plaice so much more abundant on the Continental than on the English side? There can be no doubt that the history of the plaice is the same on the two sides. We have sufficient evidence that the plaice hatched from January to March, are to be found abundantly, in summer, along the edge of the shore on the English side, wherever there is sand or sandy mud. Those of a year old, and some of those which are two years old, are the small plaice which are taken to market by the inshore boats in the Humber, and all along the coast of Lincolnshire, Norfolk, Suffolk, and Essex, and by the large trawlers from the Eastern Grounds. But the difference in numbers obtained on the two sides is enormous. On the eastern side a steam trawler brings in between 200 and 300 boxes after about a fortnight's fishing, but I have not heard of a large trawler ever having been able to get a voyage of small plaice on the English side. The cause of the difference seems to me to lie in the configuration of the sea bottom. There is a rather broad tract, less than 20 fathoms deep, extending from England to Holland, from the latitude of the Humber to that of the north coast of Norfolk. But north of this region the 20 fathom line is about 40 miles from the coast of the islands on the Continental side, from 15 to 3 miles on the English side. South of this region also there is a depression deeper than 20 fathoms, which is nearer to the English side than to the Continental. It may be true that more of the floating eggs and larvæ of plaice are carried to 
the Continental side than to the English, but this would make no difference, if food for the young plaice, and other suitable conditions, especially shallow water, were not more abundant and more extensive. We have seen that the food of the small plaice largely consists of Solen, and it is probable that the abundance of this mollusc depends upon wide tracts of shallow sandy ground in the neighbourhood of the mouths of large riverś. A somewhat similar case is that of Lyme Bay, on the south coast of England, where the 20 fathom line is a long way from the shore, and the smaller Brixham trawlers have been in the habit of taking large numbers of small plaice. In Dr. Fulton's investigations, he took a limit of $12 \mathrm{in}$., and found that plaice under this size were chiefly confined to depths below 10 fathoms, and a distance from shore less than 3 miles. This was on the east coast of Scotland : the 10 fathom line, according to the chart, is in some places 20 miles from the coast of Sylt Island.

All this, however, being admitted, it does not afford a reason why the young or small plaice should be less plentiful on the English side, off the coasts of Lincolnshire and Norfolk, where the general slope is nearly as gradual as on the Dutch and German coasts. There is another difference to be taken into account in this locality, namely, as a study of the chart will show, the existence of numerous banks and holes and rough rocky ground. The grounds are worked by trawlers, but are intricate, and necessitate short hauls, while the Eastern Grounds are noted for the slight wear and tear which they cause to the trawl, and the long hauls which can be made on them. It appears probable that the number of young plaice reared is proportional, not merely to the area of ground near the coast below 15 or 20 fathoms, but to the area of ground of a certain quality, and producing certain kinds of fish food; and a scientific, accurate comparison of the English grounds with the Continental, from this point of view, would doubtless throw much light on the "eastern question" of the North Sea trawl fishery. I hold strongly to the opinion that the business of naturalists in relation to fishery questions is to establish a sound and extensive basis for conclusions on fishery problems, by a thorough study of the physical and biological conditions of the various fishing grounds. With regard to the North Sea, it cannot be maintained that the investigations already made, valuable as they are, supply anything like an exhaustive knowledge of those conditions. On the contrary, they form merely a foundation and preparation for further progress.

In March, 1894, Prof. Dr. Heincke published in the Mittheilungen of the Deutscher Fischereiverein an article on the question of protection of undersized plaice, \&c., reviewing at considerable length the report of our Parliamentary Committee on Sea Fisheries, which sat in 1893. 
In criticising and objecting to Holt's biological limit of 17 inches for plaice, he maintained that the average size of plaice spawning for the first time is much smaller in the German part of the North Sea than in the English. He stated that as the plaice of the Baltic was, at corresponding stages, a smaller race than the plaice of the North Sea, so the plaice of the eastern side of the North Sea was smaller than that of the northern and western parts. According to Heincke, the existence of local differences made not only the same closed areas and the same close seasons for the whole North Sea, but also the same limit of size, impossible. Heincke mentions no observations which support his assertion, but it appears to rest on his own personal experience, and it will be seen, from the observations above recorded by me, that $\mathrm{Mr}$. Holt's figures were probably somewhat too high. My present conclusion is that although there is considerable variation in the size of plaice spawning for the first time, there is no difference between a German plaice and an English. To those engaged in the fish trade, it may be very beneficial to have a limit of size, to exclude the small plaice, because the uncertainty and risk of the business may be thereby diminished, whether any benefit to the fishery is produced or not. This seems to be especially the case at Billingsgate, although it is, to a certain extent, true in other markets. At the former place, I am informed that a considerable proportion of the smallest plaice are worthless, or very nearly so, and the buyer is unable to judge accurately of the value to himself of the box, as it is sold by auction. The fish at the top of the box are of considerable size, and many a poor dealer, I understand, finds great difficulty in retailing his plaice without a loss. It is certain that numbers of the smallest plaice are thrown away, both at Billingsgate and at the various shops, as worthless, and are carted away for manure. There is practically no demand for plaice 5 or 6 inches long, and dealers naturally object to have to buy the goods they require mixed with a quantity of rubbish which is of no use to them, and often to pay good money for the worthless fish. But all this has little to do with us; we are only concerned with the possibility of maintaining and increasing the natural supply of the larger plaice.

The limit proposed in the bill now before Parliament is 8 inches for plaice. It is clear, from the facts given, that the effect of this, if the law is enforced, will be to exclude the plaice mentioned above -5 to 8 inches in length. But the question is, how far this exclusion will cause the fisherman to avoid certain grounds. It is very doubtful if throwing the fish overboard will lead to thefr survival, except, perhaps, in the case of small boats fishing in places like the Humber. On the other hand, there is reason to believe that on the Eastern 
Grounds the smaller fish are nearer the land, and, to some extent, the existence of a legal limit may have the effect of causing the trawlers to fish further out, where the larger fish are. I hope to study this question by visiting the grounds on the fishing boats. At present, very little of the remuneration is obtained from plaice under 8 inches, so that the effect of the proposed law is not likely to be any very great protection of the small fish. I have always thought that the question of reproductive maturity is not the question of chief practical importance in this matter. To my mind, the question is, can a limit be discovered which will make the small plaice grounds unprofitable, without causing waste on all other grounds. So far as I can see at present, a limit of 10 inches would have conferred considerable protection to the Eastern Grounds, without causing a corresponding or considerable waste on the grounds in the open and central parts of the North Sea.

The probable, or we may say the certain, effects of a limit of 8 inches and of 10 inches can be seen, to some extent, by inspection of the data given in vol. ii., p. 347, of this Journal. The box there recorded from Arlberg, Denmark, containing 198 plaice, would not be affected by the limit of 8 inches, while the box from Schiermonnikoog, containing 286 fish, would lose only 9 . With a limit of 10 inches, on the other hand, the latter box would lose 200, and the former would lose 97 out of a total of 193. Of the Humber plaice recorded in the same list, a limit of 8 inches would exclude in one sample 224 out of 425 fish, and a limit of 10 inches would shut out all the 425 except 8.

In the report on the Dutch Fisheries for 1893, Dr. P. P. C. Hoek has published the results of some experimental trawlings made with a hired trawler off the Dutch coast. The trawl used had a beam of 35 feet in length. The mesh of the net was $2 \frac{1}{5}$ inches at the cod end, taking the length of the whole mesh, which presumably means $1 \frac{1}{10}$ inches from knot to knot. The hauls were made between Terschelling on the north, and the latitude of Amsterdam on the south, and may be considered in three groups-(1) within 6 miles of the coast; (2) 15 to 30 miles off; (3) about 55 miles off. The following are the sizes and number of plaice taken:

\section{First. Group of Trawlings.}

Sept. 15. Less than 3 miles from shore; depth, 7 to $4 \mathrm{fms}$. About 175 lbs. of plaice, number not given, size $4 \frac{4}{5} \mathrm{in}$. to $16 \mathrm{in}$; ; but of the latter only 1 in 50 fish.

Sept. $14-15$. 5 or 6 miles off; depth, 8 fms. About 43 lbs. plaice, $6 \frac{4}{5}$ in. to $10 \mathrm{in.}$ 
Sept. 15. About same distance; 9 fms. A slightly larger number, $7 \frac{1}{5}$ in. to $10 \frac{4}{5}$ in.

August 30. Depth, 11 fms. About 26 lbs., $6 \frac{2}{5}$ in. to $12 \frac{1}{5}$ in.

August 31. Depth, $8 \frac{1}{2} \mathrm{fms}$. About 175 lbs., 4 in. to $10 \frac{3}{5}$ in. ; one in 114 fish was $20 \frac{4}{5}$ in.

Sept. 1. Depth, 12 fms. About 96 lbs., $6 \frac{1}{5}$ in. to $9_{5}^{1}$ in.

For the records given a sample only was measured; but in all cases a large proportion were under 8 in., and few over $10 \mathrm{in.}$

\section{Second Group of Trawlings.}

August 24. Depth, 15 to $17 \mathrm{fms}$. 460 plaice; of 25 measured, 15 - 8 in. to $8 \frac{2}{5}$ in., $108 \frac{4}{5}$ in. to $9 \frac{1}{5}$ in.

August 28. Depth, 14 fms. 52 lbs., 8 in. to $11 \frac{1}{5}$ in.

August $29-300^{\bullet}$ Depth, $15 \mathrm{fms} .70$ lbs., 8 in. to $11 \frac{1}{5}$ in., and a few up to $14 \frac{3}{5}$ in.

Sept. 5. Depth, 15 fms. $17 \frac{1}{2}$ lbss., $6 \frac{4}{5}$ in. to $11 \frac{2}{5}$ in.

Sept. 5. Depth, 15 fms. 32 lbs., $8 \frac{2}{5}$ in. to 14 in.

Sept. 5-6. Depth, 16 fms. 119 lbs., $8 \frac{2}{5}$ in. to $11 \frac{3}{5}$ in.

Sept. 20-21. Depth, 16 fms. 119 lbs., $5 \frac{3}{5}$ in. to $10 \frac{3}{5}$ in.

This last haul was about 15 miles from the coast of the island of Terschelling.

\section{Third Group of Trawlings.}

Sept. 11-12. Depth, $17 \mathrm{fms}$. $35 \mathrm{lbs}$. smaller, $17 \frac{1}{2} \mathrm{lbs}$. larger ; 8 in. to 14 in., some up to $18 \frac{2}{5}$ in.

Sept. 12. Depth, $17 \mathrm{fms}$. 24 plaice, $7 \frac{2}{5}$ in. to $18 \frac{1}{5}$ in.

Sept. $12-13$. Depth, 17 fms. $52 \frac{1}{2}$ lbs., $8 \frac{3}{5}$ in. to $14 \frac{2}{5}$ in.

The exact proportions below different limits cannot be ascertained, but the above data indicate that a limit of 8 in. would go far to make the ground where the first group were carried out unprofitable. The different sizes on the different grounds are well brought out by the average lengths given.

Thus in the first group the averages were:-

$6 \frac{3}{5}$ in, $8 \frac{3}{5}$ in., $8 \frac{7}{10}$ in., $7 \frac{3}{5}$ in., $6 \frac{1}{10}$ ins., $7 \frac{3}{5}$ ins.

In the second group :- -

$8 \frac{4}{5}$ in., $9 \frac{3}{10}$ in., a little less than 10 in., $9 \frac{3}{5}$ in., 10 in., $9 \frac{4}{5}$ in.

In the third group :-

$11 \frac{3}{5}$ in., 12 in., 12 in.

In Denmark the limit for plaice by law is now $8 \mathrm{in}$. to the root of the tail, or very nearly $10 \mathrm{in}$., including the tail. In Belgium the limit enforced is $7 \frac{1}{5}$ in. $\left(18 \mathrm{~cm}\right.$.). In France it is $5 \frac{3}{5}$ in., while in Holland the only limit is $3 \frac{1}{5}$ in. for flounders, and there is no law for plaice. 


\section{On the Relations of the Generative Organs and of the Sexes in Some Fishes.}

Although a considerable number of observations have been made and published concerning the sizes of ripe, nearly ripe, and spent fish, and on the condition of the reproductive organs in these various stages, we are far from possessing at present a complete and satisfactory knowledge of the changes through which these organs pass in the development of the fish to maturity, and from one spawning period to the next. This is in fact a subject where investigation requires minute microscopic study, and the application of advanced microscopical science; and the investigation is necessarily an extended one, because it involves a complete examination of all stages in a given fish, and a comparison of all the different fishes with one another. I have a few observations and suggestions to offer here in addition to those contained in my papers on the subject in previous numbers of this Journal.

The first point I wish to consider is the remarkable difference in proportional size between the ovaries and testes in different species, and in relation to this, the differences between the sexes in number and size. To Dr. Fulton belongs the credit of having first drawn attention to these phenomena, and he has published some important data concerning them, and suggested some explanations. (See his papers in the 8th, 9 th, and 10th Reports of the Scottish Fishery Board). It is well known that in some fishes, as in the herring, the testes or soft roes are as large as the hard, and the same is true of Clupeoids generally. In the cod family it is difficult to judge without accurate weighing, but the testes, which are of a curious frilled shape, quite different from that of the ovaries, do not appear obviously smaller than the latter. In the flat-fishes, on the other hand, the testes are always smaller than the ovaries, and the minimum is reached in the sole, where they are so small as to have been formerly entirely overlooked. Dr. Fulton has given the actual weights of the organs in a number of specimens, but has not worked out the proportion they bear to the weight of the fish. From averages of 10 male herrings and 16 females it was found that in fish of $11.2 \mathrm{in}$. in length the testes weighed 35.6 grammes, the ovaries $35^{\circ} 0$, so that the testes were actually a little heavier. In a male cod $39 \mathrm{in}$. long the ripe testes weighed 846 grammes, while in a female of 38 in. the ovaries weighed 2,124 gms., or more than twice as much. A difficulty in exact comparison arises from the varying conditions of the organs, whether in the development towards maturity, or whether the discharge of products after spawning has commenced; all that can be done is to compare them just before the commencement of spawning. 
In a male plaice $21 \mathrm{in}$. long the testes weighed 29.5 grms.; in a female $23 \frac{3}{4}$ ins. the ovaries weighed 503 grms. In the lumpsucker, in a male $12 \mathrm{in.}$ long the testes weighed 70.8 grms., in a female $17 \mathrm{in.}$ long the ovaries weighed 878 grms.

If the small size of the testes were compensated by the greater abundance of the males, an approach to equality in the quantity of the generative products might be the result. But the opposite of this, according to Dr. Fulton's researches, is usually the case. Thus in the cod there were found to be 133 females to 100 males, in the plaice 142 females to 100 males, but in the lumpsucker there were only 25 females to 100 males, and in the herring the numbers of the two sexes were very nearly equal. Dr. Fulton considers the probable significance of these relations, and concludes that the testes are usually smaller in fish with pelagic ova, and more nearly equal in those with adhesive ova, and he thinks the explanation is that fertilisation is more certain in the case of pelagic ova, because the sperms move upwards like the eggs, while in the case of attached ova a great deal of the milt is wasted. There is probably much truth in this suggestion, but I would put it in a somewhat different way. In the sea the water is generally moving in one direction or another, and the milt shed into the water disperses by diffusion, even without the movement of a current. Therefore, if the eggs are fixed, much of the milt must travel away from them, and more of it is required. Where the eggs are free in the water like the milt, they scatter together, and are moved together by the currents. It is remarkable, however, that in the angler, of which the eggs, though free in the water, remain connected in a continuous sheet, the males are much more numerous ( 100 males to 26 females), and the males are also larger, though whether the testes are larger than the ovaries has not been ascertained.

But the proportion in bulk between testes and ovaries differs very greatly among fishes which agree in having pelagic ova. For instance, in the cod the inferiority of the testes is very much less than in the plaice, and in the plaice than in the sole, while in the flounder, although the testes are smaller, the males are more numerous than the females. It seems to me that these differences are to be explained by the differences in the rate of spawning. Some fishes, like the herring, shed the whole crop of eggs for the season at once. The eggs are all in the same stage of development, and therefore are all ripe at one time, and when spawning begins it continues at a rapid rate until the roe is empty, and the fish is spent. Plaice and cod do not spawn so rapidly as this, but it is certain that in both these fishes a large number of eggs can be squeezed from a ripe female at one time, so that the roe is soon emptied. The rate of spawning, and its duration, can be studied by 
examining the ripe and ripening ovaries, as Dr. Fulton has done to a great extent in his investigation of the fecundity of fishes. In some cases, although the number of ripe eggs present is considerable, there are others in various degrees of development, so that spawning is prolonged. This is the case in the gurnard, and in some fishes with attached ova, such as Syngnathus acus, Anarrhichas lupus (the cat fish) and others. In the plaice, according to my own experience, and Dr. Fulton's observations, a large number of ripe ova are shed at once, and the season's crop is soon exhausted. There is no prolonged production of young ova to succeed those first shed. The fish being of a high degree of fecundity, and having all its eggs nearly ripe at once, the distension of the body by the ripe ovaries is very great. In accordance with this state of things the testes are rather large, very much larger than in the sole, and spent fish appear early in the spawning season. The spawning process being thus completely and abruptly terminated, the ovary reverts to a resting condition. At Plymouth I found a spent specimen as early as January 28th, at Grimsby the first I recognised was obtained on February 27th. The conclusion that the ovary does revert to its original condition, based on the evidence given in my paper on the ovaries of fishes, vol. iii., p. 154, has been confirmed by my observations this season at Grimsby. It has been shown in former papers by Mr. Holt and myself, that in the spent ovary the chief peculiarity is not the appearance of empty follicles from which ripe eggs have escaped, but the presence of partially yolked eggs, which are found to be afterwards absorbed. But the opaque granular masses to which I have so often referred above, had not attracted my notice very much before the present season. They are easily overlooked, not because there is any difficulty in seeing them, but because they are so indefinite in shape, and do not appear at first to have any important significance. The history of the ovary could be worked out with more certainty if we were able to examine specimens in captivity, the date of whose spawning was known from actual observation. I have in a former paper described a few such specimens, but they were not killed until several months after spawning.

I have not yet made a thorough examination of shotten herring, but the few notes I have made tend to show that in the spent ovary the ova are all quite yolkless and transparent, as in the immature ovary. A newly-spent herring can be recognised from the flaccid and congested condition of the ovary, but it is extremely probable that this condition soon passes away.

The haddock presents a condition similar to that of the plaice, that is to say the spawning of an individual fish is soon over, the development of the eggs being nearly simultaneous. On April 20th I examined 
6 specimens in which the condition of the reproductive organs was as follows :-

Length of fish $14 \frac{3}{4}$ in. Testis a thin translucent cord: fish apparently immature.

Length 15 in. Female, ovary small, $1 \frac{1}{4}$ in. long, no yolk, no granular masses: apparently immature.

Length $17 \frac{3}{4}$ in. Female, ovary spent, $1 \frac{2}{16}$ in. long, much mucus in cavity. In the germinal tissue yolkless eggs and dead partially yolked eggs as in spent plaice, but the latter were few and scattered.

Length $19 \frac{3}{4}$ in. Female, ovary $2 \frac{1}{8}$ in., spent. Same condition as in preceding.

Length $20 \frac{1}{2}$ in. Female, spent; same condition.

Length $20 \frac{1}{2}$ in. Male, spent, testis almost invisible.

There can be little doubt here about the rapid recovery of the ovary, and the danger of confusing immature with recovered fish.

On the other hand, in the lemon dab and common sole, the spawning process in a single female is gradual and prolonged, and spent females do not appear early in the spawning season. When a ripe ovary of these two species is examined, the eggs are not found to be nearly uniform in development, but to form a graduated series down to the minute. In spite of this similarity I have observed that a large number of ripe eggs can be obtained at one time from a lemon dab, and the testes are of considerable size, but still, according to Dr. Fulton's figures, smaller in proportion to the ovaries than in the plaice. The witch appears to resemble the plaice, the eggs developing uniformly, and the testes being rather large.

I have examined a few witches at Cleethorpes. The size of mature and immature specimens has not been so carefully studied in this species as in others. On February 18 th I examined 6 specimens. Two were males, both mature, $15 \frac{1}{2}$ and $16 \frac{7}{8}$ in. long; four were females, $16 \frac{1}{2}$ to $18 \frac{5}{8} \mathrm{in}$, and all mature, but not ripe; that is to say, the ovaries were enlarged, and the development of the yolk in the eggs advanced. On February 23rd I examined 4 more, all females, 15 in. to $19 \frac{1}{2}$ in. long, and all mature.

Mr. Holt found some lemon dabs immature at 12 in., and 50 per cent. of the females at $11 \mathrm{in.}$ At Plymouth I examined numbers of females down to $7 \mathrm{in}$. long, and none were immature. My observations were made from January to March, Mr. Holt's between February and September. On February 18th last I examined 6 specimens: 2 were mature males, $12 \frac{1}{8}$ and $12 \frac{1}{2}$ in. long, 3 were mature females, $12 \frac{1}{2}$ to $13 \frac{3}{4} \mathrm{in}$.; and one $9 \frac{1}{4} \mathrm{in}$. was an immature female. There could be no doubt about the last specimen, as no spent females were to be found at that date. 
In all the fish hitherto mentioned there are no oil globules in the ripe egg, and the development of the yolk follows the course which I have described in my two papers, vol iii. pp. 154 and 258. In all these cases I have satisfied myself that the development of the yolk in the eggs takes less than a year. In other words the formation of the crop of eggs for the next spawning season does not begin until some time, about three or four months, after the preceding spawning. But in my paper, vol. iii. no. 2, I described in the egg of the sole the presence of minute globules in the ova of immature females during the spawning season, and in spent females. Recent observations have shown me that these minute globules occur only in those eggs in which oil globules are present in the ripe condition, and I conclude that the deposit of oily matter commences in the ova long before that of yolk proper.

On April 8th I examined 3 small brill, procured from a lot of 34 , brought with 4 small turbots and 120 boxes of small plaice from the Sylt Grounds. One was $9 \frac{1}{4}$ in. long, a male not ripe, but with testes rather large and soft, evidently approaching ripeness. One was $11 \frac{1}{8}$ in., a ripe male. One was $11 \frac{1}{2}$ in., a female, the end of the ovary $4 \frac{1}{4}$ in. from the anterior end, $4 \frac{7}{8}$ from the posterior end of the ventral fin. All the ova under the microscope were transparent, but except in the very smallest there were small, clear globules, principally collected round the germinal vesicle. I think this specimen could not have matured its eggs during the present spawning season, and would not have been ripe for at least 12 months. On April 22nd I examined another specimen, $15 \mathrm{in}$. long, in which the left ovary was $3 \frac{7}{8} \mathrm{in}$. long and $5 \mathrm{in}$. from the end of the ventral fin. There was nothing to indicate that this specimen was spent, all the ova were transparent, but here and there one showed the scattered globules I have mentioned. This specimen was presumably immature.

On April 24th I examined the ovaries of two turbot. One was $19 \frac{3}{4}$ in. long. The roe was opaque white from the development of yolk, and obviously approaching maturity. Under the microscope the yolk in the eggs was in all stages of development. In some there were only the peculiar globules I have mentioned, in others a little larger, these were more numerous, and began to form a dark zone round the germinal vesicle, while in the outer part of the egg were globules of ordinary yolk of a much lighter appearance. In all the eggs in which the development of yolk was considerable, there was an inner darker and an outer lighter zone. The other specimen was $15 \frac{1}{2}$ in. long, and the formation of the dark inner zone had commenced in an egg here and there. Apparently this specimen would have spawned this season. 
On April 26th I examined a number of Trigla gurnardus. I did not note the sizes of these, but all were mature, and in most of them there were some ripe eggs. In each ovary there was every stage of development, from the transparent egg with a few globules to the large also transparent ripe egg, with its large single copper-coloured oil globules. As in the turbot, what may be called the second stage consisted in the formation of a dark inner zone round the germinal vesicle, with scattered globules in the outer region. In the next stage the egg is full of yolk, no clear protoplasm is visible, but there is a marked contrast between the dark inner zone and the light outer. In the fourth stage the contrast is less marked: the dark inner zone appears to consist of very minute globules of oil, and at this stage they run together and form large globules, in consequence of which the inner zone becomes more translucent. In the fifth stage the coalescence of the inner globules and of the outer into larger and larger drops can easily be seen, and it is perfectly obvious that the inner drops form the oil globule of the ripe egg. Thus the oil globule originates in the central part of the egg, and only rises to the surface when the whole yolk becomes a continuous liquid.

These facts considerably modify the criticism I have given in vol. iii. p. 263, of Scharff's account of the development of the egg. I have not his paper here to refer to, but he worked with the eggs of Trigla gurnardus, and described the division of the protoplasm of the egg into two layers. In the eggs of plaice and flounder I could only find an outer yolk layer and an inner without yolk. I have now shown that there are at any rate two types in the development of yolk in the eggs, one characterising the eggs without oil globules, the other those that possess the latter. In the ovaries of fish whose eggs possess oil globules, the presence of minute scattered globules, in otherwise protoplasmic eggs, does not imply the "active" condition of the ovary-does not, that is to say, prove that the maturation of the ovary for the next spawning season has commenced. It seems to me quite possible that in these fish also a spent ovary may revert to the condition of the immature, but on this point we have at present little or no evidence. The dark inner zone in the developing eggs above described appears to be due to the presence of exceedingly minute and numerous globules of oily matter, which by their great sub-division and refracting power cause the opacity of that part of the egg.

\section{Two Trips to the Eastern Grounds.}

In order to acquaint myself, by personal examination, with the condition of the Eastern Grounds, and the products of the trawling New Serizs, - Vol, IV., No. 1. 
there carried on, I have made two trips on board steam trawlers bound to those grounds. On my first voyage, I left Grimsby. Docks on May 14th, on board the s.s. Lucania, belonging to the Alliance Company. The run was about 260 miles E. $\frac{1}{4} \mathrm{~N}$. When we reached the neighbourhood of the Horn Reef on the 15th, it came on to blow, and we lay-to for twenty-four hours without shooting the trawl. This was the commencement of the disastrous gale, which continued, with little interruption, on the English side of the North Sea, until Monday, May 20th, but on the German, or eastern side, it moderated on Thursday evening, and for the rest of the trip we had very fine weather.

The trawl was first shot on the evening of May 16th, and hauled at 11 p.m., but I did not make any observations until the second haul, at 6 a.m. on the 17 th. The position, then, according to the captain, was thirty miles south of the Horn Reef, twenty miles west of the Sylt. The marketable fish taken were haddock, cod, and plaice. Of the last, the smallest was $12 \frac{1}{4} \mathrm{in}$. long. The refuse consisted of whelk spawn and crabs (Hyas araneus and Cancer pagurus). The bottom was sand and broken shells; there were pieces of shell on the net.

During the third haul the depth was 11 to 13 fathoms, and the bottom consisted of coarse sand, called rice-ground by the captain. A tow net was put on the trawl head, and the tin at the end of it came up half full of this sand, in which were three living specimens of Amphioxus. The fish caught were 2 baskets of plaice, none under 12 in., 14 baskets of haddock ( 9 of kit and 5 of gibbers), 23 cod, 2 turbot 1 brill; none of the turbot or brill under 12 in. The stomachs of the plaice contained Solen.

The fourth haul, lasting like the preceding six hours, was concluded at 8 p.m. on the 17th. A net of mosquito-netting on the trawl head, brought up a number of larval flat-fishes in process of transformation, probably plaice and dabs, and also one sand-eel. The fish in the trawl were 14 baskets of haddocks (10 of kit and 4 of gibbers), several cod, $3 \frac{1}{2}$ baskets of plaice, the smallest of these being $11 \frac{1}{2}$ in. by measurement. There were 2 lemon soles, one of them $8 \frac{3}{4}$ in. long. A large number of dabs were obtained in this and all other hauls, but were not saved for the market, their value, after being iced for some days, not being considered sufficiently great. A few of the largest were cleaned for the cabin table, the rest thrown overboard. The haddocks' stomachs contained brittle stars; these, and all other marketable fish, were gutted before being packed away in the fish hold. Edible crabs occurred in every haul, but were not saved for market, only a few being eaten on board.

At the fifth haul, at 3 a.m. on May 18th, were taken 22 baskets of haddock ( 7 of gibbers and 15 of kit), and 2 of plaice. A larger number of haddock are usually taken at night than in the day-time. 
At the sixth haul, at 10.30 a.m., the catch comprised 8 baskets of haddock, 3 of plaice, 1 turbot, 1 hake, 5 codling, a few whiting, numbers of dabs, and 1 gurnard. The smallest plaice was $10 \frac{5}{8}$ in. long.

Seventh haul, 5 p.m., May 18th. 9 baskets of haddock, viz., 3 of gibbers, 6 of kit, 2 baskets of plaice. 1 turbot, $28 \frac{1}{2}$ in. long, a female, nearly ripe; 1 brill, $13 \frac{1}{2} \mathrm{in}$. long, approaching ripeness. The food of the plaice was, as usual, Solen.

During the eighth haul the vessel was steered first N.N.E., and then S.S.W., the depth was 13 fathoms and the Inner Horn Reef light was seen, bearing E. by. N., distant about ten miles. I could not obtain the exact position for every haul, but it must be understood that trawling was carried on without interruption, so that one or two fixed points are enough to indicate the fishing ground. A steamer carries two trawls, one on each quarter, and as soon as one was hauled, the other was shot. As we were keeping in the same neighbourhood, the vessel was steered on one course for about three hours, and then on the opposite course for the remaining three. It may be pointed out, that the principal part of the catch in these hauls was the haddock. At the eighth-a night haul-there were 8 baskets of gibbed haddock and 20 of kit, and only 2 baskets of plaice.

Ninth haul, 8 a.m., May 19th. The foot-rope was broken and the net torn, an indication of rough ground. The marketable fish were, 8 baskets of gibbers, 16 of kit, 2 of plaice, 4 brill, 2 turbot, about 20 cod, 1 halibut. The kit haddocks measured about 15 in. long, the gibbers 20 to 26 in. The smallest plaice was $12 \frac{1}{2}$ in. long, the largest 26 in. Of the brill-2, 13 in. and $14 \frac{1}{2}$ in. respectively, were immature females; 2,14 in. and $16 \frac{1}{2}$ in. in length, were ripening. Of the turbot- $1,13 \frac{1}{2}$ in., was an immature female; the other, 14 in., a mature male. The smallest cod was $13 \mathrm{in}$. long, the rest were about $3 \mathrm{ft}$.- -some more, some less. The stomach of one large cod contained 4 sand-eels and 2 crabs (Inachus); another contained 12 sand-eels; another a large crab (Hyas). The halibut was $4 \mathrm{ft}$. $8 \mathrm{in}$. long, a spent female, and had 10 haddocks in its stomach.

Tenth haul, 6 p.m. ; depth, 13 fathoms. The trawl was down nine hours this time, the day being Sunday. There was in the net 1 mackerel -a ripe male; 3 hake -2 males, 1 female, mature, but not ripe; 7 large turbot, female, mature, but not ripe; 1 brill, over 12 in.; 1 sprat, a ripe female; 4 baskets of kit haddock, $\frac{1}{2}$ basket gibbers; 2 baskets of plaice. In the stomach of one of the turbot were 3 sprats and 2 sand-eels. A few large mackerel were also got at the eleventh haul.

Twelfth haul, 8 a.m., May 20th. During this haul, at 2 a.m., the Outer Horn Reef Light was seen, bearing N.E. by N., and distant about 10 miles. The net brought up 9 baskets of kit haddock, 2 of gibbers, 
3 of plaice, 1 of gurnard (Trigla gurnardus), 2 turbot, one $14 \mathrm{in.}$ long, a mature male, one 24 in., a mature female; 25 large cod, and some small. As usual, there were no small plaice, but many large, $20 \mathrm{in}$. long and upwards.

Thirteenth haul, 5 p.m. The depth of 15 fathoms was obtained by the lead. There were 7 turbot-2 mature females, $29 \frac{1}{2}$ in. long, 5 mature males, $14 \frac{1}{2}$ to $21 \frac{1}{2}$ in.; 2 brill, $17 \frac{1}{2}$ in. and 20 in., both mature females. Also 10 baskets of kit haddock, 3 of gibbers, 3 of plaice, and 1 of gurnards. About half a basketful of small haddocks, about $10 \mathrm{in.} \mathrm{long,}$ were shovelled overboard with the dabs. The smallest of these were $6 \frac{1}{2}$ in. long, but there were few as small as this. The smallest dab was $5 \mathrm{in}$., an immature female, but nearly all of them were mature and spawning, many being nearly spent.

Sixteenth haul, 4.30 p.m., May 21st. There were $3 \frac{1}{2}$ baskets of kit haddock, 1 of gibbers, $3 \frac{1}{2}$ of plaice, $1 \frac{1}{2}$ of gurnards, a few codling and roker. The plaice were nearly all large, none under 12 in. There was 1 brill, $12 \frac{1}{4}$ in., an immature female; no turbot. 1 Acanthias vulgaris and 1 Echinus were taken.

At 6.30 p.m. we were steering E. by N., the depth 13 fathoms, bottom fine sand. We saw the Outer Horn Reef Light after dark.

Eighteenth haul, 5 a.m., May 22nd. There were 2 turbot, $25 \frac{3}{4}$ in. and $27 \frac{1}{2}$ in., both mature females ; 3 brill, $15 \frac{1}{2}$ to $18 \frac{1}{2}$ in., all mature females; 1 basket of large plaice, none under $12 \mathrm{in}$., about a basketful of haddock and one of gurnard.

In the last, or nineteenth haul, there were 2 soles, one $7 \frac{1}{2}$ in. long, a male, immature, one $11 \frac{1}{4}$ in., a male, mature. A few other soles were taken during the voyage, but never more than 2 or 3 in one haul. Roker, i.e., Raia clavata, and other species, were also taken, but I paid no particular attention to them. The most important points noticed in this voyage are the following :-

No small plaice were thrown overboard, because none were taken of so small a size as to be unmarketable. None of those taken were less than $10 \frac{5}{8} \mathrm{in}$. long, and a large proportion were $20 \mathrm{in}$. and upwards. The captain said that when we were in sight of the Inner Horn Reef Light, we were on the same ground on which he obtained chiefly small plaice in the previous March. Whatever the significance of that fact may be, supposing it to be correct-and I have no reason to doubt itit is certain that the small plaice were not there in May.

Only two or three lemon soles and an insignificant number of soles were taken. A few immature turbot and brill were observed, but none were under $12 \mathrm{in.} \mathrm{in} \mathrm{length.}$

The only fish thrown overboard were the dabs, a comparatively small number of small haddock, and some small gurnard and whiting. 
After my return from this voyage, I noticed in the market that the catches from the Eastern Grounds often included large numbers of small brill and turbot, and a considerable quantity of soles. Thus, on May 30th, a vessel which had been fishing 10 miles off the Sylt Light, at about 13 fathoms, landed about 200 boxes of small plaice, 3 boxes of soles, 130 small brill, and 28 small turbot. By small here, I mean brill and turbot about 12 in, in length, very few of these fish exceeding 14 in. I bought a sample of the brill for examination, not selecting them in any way There were 20 in the sample-3 males, 17 females. The smallest female was $10 \frac{3}{4} \mathrm{in}$., the largest $12 \frac{3}{4}$ in., and all were immature. On examination of the ovarian tissue with the microscope, a few of the eggs, in nearly all the specimens, were found to contain the scattered central globules, which I have mentioned elsewhere, as occurring in immature brill and turbot. The three males were from $10 \frac{1}{4}$ to $11 \frac{1}{2}$ in. in length; the smallest was sexually ripe, the other two nearly, but not quite so.

On June 1st I bought a box of small plaice, brought from the ground off the Sylt. The price of this was $3 \mathrm{~s} .9 \mathrm{~d}$. It contained 360 fish211 males, 149 females. It is of importance to note that the males were the more numerous, although it is known that the females are more numerous in plaice on the whole. The smallest male was $7 \frac{5}{8} \mathrm{in}$. long, the largest $11 \frac{1}{2}$ in. There were 3 males under 8 in., 131 under 10 in. The smallest female was $7 \frac{3}{8}$ in., the largest 13 in. There were 4 females under $8 \mathrm{in}$., 86 under $10 \mathrm{in}$. The total number in the box under 8 in. was 7 ; the total number under 10 in. 217 , or 60 per cent.

I examined the roes of a few of the females microscopically, with the following results :-

Plaice $7 \frac{3}{4}$ in. long. Ova all yolkless; no opaque masses.

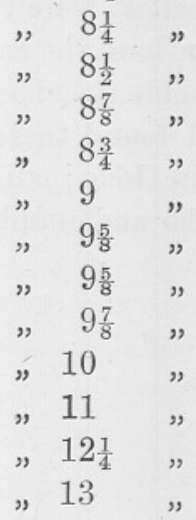

A few opaque masses, or dead yolked eggs.

No yolk, no opaque masses.

No yolk, a few distinct granular masses.

On Monday, June 3rd, I examined in the market the fish landed from a steam trawler, which had been fishing about 21 miles off the 
Amrum Light, i.e., to the north of Heligoland, and was struck with the very large number of small brill and turbot in her "voyage." I found, by actual count, that she had 646 small brill and 150 small turbot. Many of these brill were under $12 \mathrm{in}$. and many of the turbot. There were also 26 larger brill, and 10 larger turbot, the largest of the former being $20 \mathrm{in}$. long, of the latter, $28 \mathrm{in}$. The rest of the catch included 61 boxes of medium plaice, 100 boxes of small and 7 boxes of soles. The last were by no means undersized. On this same vessel I went to sea the next day, to make observations during her fishing.

We steered E. $\frac{1}{2}$ S. from the Newsand Lightship. The trawl was first shot a little before twelve (midnight), on June 5th. The position was about 18 or 20 miles west of the Sylt; the depth 13 to 14 fathoms.

First haul, 6 a.m., June 6 th. The marketable fish were: 5 baskets of kit haddock, 2 baskets of plaice, none small, 4 cod, rather small, 2 coal fish, 6 turbot. Three of the turbot were females, 2 of them $29 \frac{1}{8}, 31 \frac{1}{2}$ in. ripe, $1,21 \frac{1}{2}$ in., 2 others were mature males $13 \frac{1}{2}$ in. to $20 \mathrm{in}$. The largest turbot yielded ripe eggs freely, and was nearly spent after I had squeezed it: this shows that the turbot, like the plaice, sheds a large number of eggs at once, especially towards the end of the spawning process. The refuse thrown overboard consisted of small haddocks, dabs, gurnards and whiting. There were also half a basketful of common whelks; Cancer pagurus, many; whelk spawn, quantities; Asterias rubens, many; Solaster papposus, many; Alcyonium digitatum, quantities.

Second haul, 11.30 a.m. At the beginning of this shot we towed S.E. $\frac{1}{2}$ E. depth $12 \frac{1}{2}$ fathoms. Just before hauling we got 11 fathoms. When the fish were on the deck I saw that we were now on the small plaice grounds. The plaice kept for market were sorted by the crew into two classes, according to their size, and the smallest were thrown overboard. I found that the smallest saved was $11 \mathrm{in}$. long, the smallest in the whole catch was $6 \frac{1}{2}$ in. long. After the valuable fish had been picked up the rest were left for me to examine: I found there were about two baskets of plaice, the largest being $10 \mathrm{in}$. long; all these were shovelled overboard, with a few small haddocks and numbers of small dabs. The fish kept were :-

$1 \frac{1}{2}$ baskets large or medium plaice.

$1 \frac{1}{2} \ggg \quad$ small plaice.

2 " haddock.

$\frac{1}{2}$ " dabs.

18 pair of soles, none under 8 in.

1 coal fish, 1 Trigla hirundo.

5 turbot, $11 \frac{1}{2}$ in., 13 in., 14 in., 14 in., $19 \frac{1}{2}$ in.

3 brill, 11 in., 13 in., 13 in. 
It is evident that the plaice thrown overboard by the captain of this vessel would have been all taken to market by many captains, because I have seen numbers of plaice from 6 to $10 \mathrm{in}$, in the market at Grimsby.

Third haul, 5.30 p.m. During this shot the vessel was steered first to the S. and we passed near the Amrum Bank, sounding 8 fathoms, coarse sand; then we steered to the W.S.W. As soon as the other trawl was shot, the men began picking out and gutting the fish, shovelling over the worthless fish as they proceeded, to get them out of the way. Some of the small plaice and dabs first thrown over were, therefore, alive: whiting and grey gurnard were also rejected. The fish kept were :-

1 baskets medium plaice.

$\begin{array}{lll}3 \frac{1}{2} & \text { " small } \\ 1 \quad & \text { haddocks. } \\ 1 & \text { " cod and dabs. } \\ 32 & \text { pair of soles. }\end{array}$

The smallest plaice kept was $10 \mathrm{in}$. long: many of those thrown overboard were over $8 \mathrm{in}$. In reckoning the number of soles, only the larger are counted as pairs, a good many smaller, called slips, not being counted, although taken to market. There were also 28 brill, the largest of which was $17 \mathrm{in}$. long. I measured and examined these carefully. 21 of them were immature females, the smallest being $11 \mathrm{in}$. long. Leaving out fractions of an inch, 5 of these were $11 \mathrm{in.} \mathrm{long;}$ 9, 12 in.; 5, 13 in.; and 2, 14 in. Two were mature females, $15 \frac{1}{2}$ in. and $17 \mathrm{in}$. respectively. The remaining 5 were males, all immature, though they would probably have become ripe later in the season: 4 of them were $11 \mathrm{in.} \mathrm{long,} \mathrm{one} 12 \mathrm{in}$. In examining brill and turbot on board ship, I have put down all females as immature which had no yolk in the roe, judging that they would not have spawned this season, while those in which the roes were in process of maturation I have called mature, though many of them had not begun to spawn, and probably had never spawned in their lives when caught. Of these 28 brill then, 9 were under $12 \mathrm{in}$., and 21 females and 5 males were immature. The turbot were 5 in number, 3 of them immature females, 2 mature males. The females were $11 \frac{3}{4}, 12 \frac{1}{4}$ and $14 \mathrm{in}$. long, the males $11 \frac{3}{4}$ and $13 \mathrm{in}$. long. There were also taken 2 specimens of Trigla hivundo, known to the Grimsby fishermen as latchets, to the Plymouth men as tubs; these were large mature fish; and 1 lemon sole $8 \frac{3}{4} \mathrm{in.} \mathrm{long.}$

Fourth haul, 11.30 p.m. During this haul the vessel was steered somewhat away from the coast into deeper water, namely, 12 to 13 fathoms. It being dark when the trawl came up, I could not examine the fish very completely. As in other similar cases, I contented myself 
with making a note of the fish saved according to the information given me by the mate: they were:-

9 baskets of haddocks.

1. " " medium plaice.

1 score cod.

11 pair of soles.

1 turbot, 2 small brill.

2 latchets.

Small plaice occurred in insignificant numbers.

Fifth haul, 6. a.m., June 7th. Soon after the trawl was shot, at 12.25 a.m., the Amrum Light was seen just on the horizon, about 20 miles distant. The vessel was steered towards the land, and just before hauling we sounded 10 fathoms, near the edge of the Amrum Bank. The fish of this haul were also not completely examined by me; there were saved:-

3 baskets medium plaice.

$5 \frac{1}{2} \quad$ " haddock.

18 pair of soles.

Nearly a basket of turbot and brill, some small.

3 large cod, some latchets.

Very few small plaice.

Sixth haul, 9 a.m. The trawl was hauled up after being down about two hours, in consequence of an accident in putting over the buoy. The captain gave orders to put out the usual buoyed flag-staff to mark this ground, where the fish was fairly plentiful, and when the anchor and line belonging to the apparatus were thrown overboard they were caught by the trawl, and it became necessary to haul.

The largest plaice was $15 \mathrm{in}$. long, the smallest $8 \frac{1}{2} \mathrm{in}$. There were 11 turbot and 15 brill, 3 turbot and 1 brill being under 12 in. Of latchets, 11 were taken; one I opened was a female approaching ripeness, with about 6 sand-eels in the stomach. The latchets were not considered very valuable fish: none were thrown overboard, but a considerable number were eaten on board: the other fish taken for cooking were dabs, whiting, and roker, and occasionally small plaice. The fish thrown overboard from this haul were plaice up to 11 in., dabs up to $11 \frac{1}{2}$ in., and also some grey gurnard and whiting. The other fish saved were:-

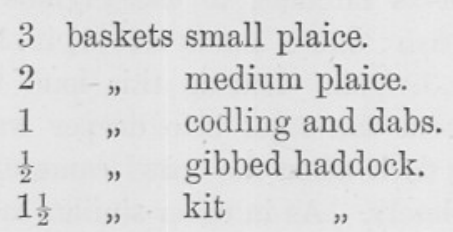


Seventh haul, 2 p.m. The depth where the buoy was put down was 12 fathoms. In this haul there were 4 turbot and 6 brill under 12 in., out of a total of 18 turbot and 24 brill: this is nearly 25 per cent. One brill, about 8 in. long, was thrown overboard dead. There were 18 pair of soles, none under $8 \mathrm{in}$., few, if any, under $10 \mathrm{in}$. There were 8 latchets. Of the rejected fish the plaice were $7 \frac{1}{4}$ to $10 \mathrm{in}$., the haddock about $11 \frac{1}{2}$ in., the whiting about 13 in., and a number of grey gurnard were also thrown over the side. There were saved:-

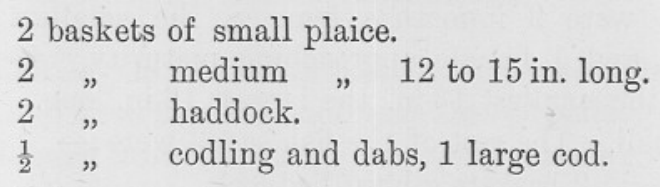

It is difficult to estimate exactly the number, or quantity, of small plaice thrown overboard from this haul, but roughly, there were about 2 basketfuls, besides the dabs, gurnards, small haddock and whiting.

When the trawl came up, I was called to see a small sole, caught in a crevice of the ground rope. It proved to be a Solea lutea.

I did not see a sole less than 9 or $10 \mathrm{in}$. in length all the voyage and believe that, if caught at all, they escape through the meshes. Several of the smaller that are caught are nearly through the meshes when the net is hauled and are dragged through by the men, by hand, as the net comes up.

Eighth haul. Trawl up at 8 p.m., after fishing round the buoy. There were 90 turbot and brill, all rather small, but I only noted 2 turbot and 3 brill under $12 \mathrm{in.}$. Of plaice, the smallest in the haul was $7 \frac{1}{2}$ in. long; 2 baskets of the medium size were saved, they were from $12 \frac{1}{2}$ to $15 \frac{1}{2}$ in. long; also 2 baskets of small, 10 in. to $12 \frac{1}{2}$ in. About 3 basketfuls were thrown overboard. There were 30 pairs of soles, the smallest $11 \frac{1}{2}$ in. long. As usual, there were some latchets, and 1 Acanthias vulgaris was taken. 2 baskets of haddock were saved.

Ninth haul, 2 a.m., June 8th. At the commencement of this haul, the Amrum Light was seen on the horizon, bearing E. by $\mathrm{N}$. and distant about 20 miles ; this gives, with sufficient accuracy, the position of the fishing ground. A lantern was attached to the top of the buoyed flagstaff, at dusk, the previous evening. The fish saved were :-

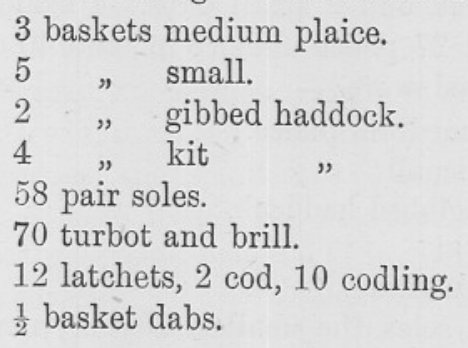

হ " groveu наuиock.

3 large cod.

30 pair of soles. 
Tenth haul, 8 a.m., June 8 th. There were very few small plaice this haul and few brill, but turbot and haddock were plentiful; soles were also scarce. The vessel had been further to the westward, although the depth, namely, 10 to 12 fathoms, had not been much greater. I made a careful examination of the turbot. There was one ripe female, $24 \mathrm{in}$. long and several ripe males. I fertilised the spawn from this specimen and threw it overboard, that it might not be wasted, as the only bottle available already contained fertilised turbot spawn. There were 9 immature females, the smallest $13 \frac{1}{2}$ in., the largest $15 \frac{1}{2}$ in., and 1 female approaching maturity, $14 \frac{3}{4}$ in. long; 12 mature males, the smallest 13 in., the largest 16 in. long. There were 7 brill, rather small. The rest of the fish saved were :-

2 baskets gibbed haddock.

$$
\begin{aligned}
& 4 \frac{1}{2} \text { " kit " medium plaice } \\
& 2 \text { " } \quad 10 \frac{1}{2} \text { to } 12 \text { in. } \\
& \frac{1}{2} \text { small pair of soles. } \\
& 14 \text { large latchets, } 2 \text { or } 3 \text { small. } \\
& 1 \text { basket of cod. }
\end{aligned}
$$

Eleventh haul, 2.30 p.m., June 8 th. This haul we again got more brill, soles and small plaice, and fewer haddock, having steered towards the land again. 3 small plaice, put into a tub of clean water after the men began to gut the fish, lived vigorously for some time, until they were thrown overboard. Many of the small plaice were alive when the first shovelfuls were thrown over. The smallest of them was $6 \frac{1}{2} \mathrm{in}$. long and there were numbers 7 in.; one of the latter measured $2 \frac{1}{2}$ in. across the broadest part of the body, excluding the fins. The mesh at the cod end of the trawl is nearly 3 in. in length when elongated and it seems strange that plaice of this size do not escape. The reason is that the skeleton is rigid, and the strong anal spine acts as an obstacle; the young plaice, too, has no instinct towards working its way through an aperture as the sole has, and none of the required agility-its only instinctive movement, when disturbed, is to flap its body up and down. The smallest fish in the haul was a dab $4 \frac{1}{2}$ in. long, an immature female.

There were 47 turbot and brill-of these, 5 turbot, and 9 brill, were under $12 \mathrm{in.}$ The smallest turbot was $8 \frac{1}{2} \mathrm{in}$. long, and its stomach contained 2 sand eels, and 2 small dabs. I examined a sample of the refuse: it contained 27 plaice under 8 in., and 40 over that limit. The rest of the fish saved were:-

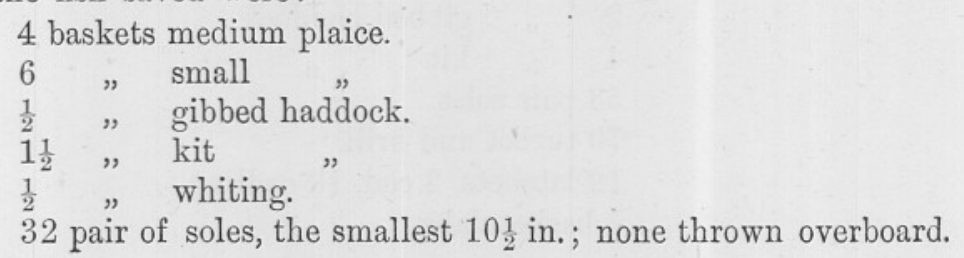


Twelfth haul, 8.30 p.m., June 8 th. At 7.45 p.m. we sighted the island of Heligoland and then turned round and steered north. We lost the buoy, the day having been very foggy, and were unable to find it again. A large specimen of the tope, Galeus vulgaris, was caught in this haul; it was a male and measured $3 \mathrm{ft} .8 \frac{1}{2}$ in. The fish saved were:-

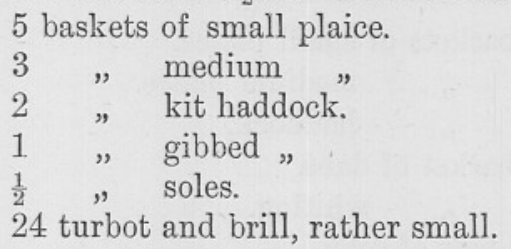

A quantity of small plaice and dabs thrown over.

Thirteenth haul, 2 a.m., June 9 th. At 9.30 p.m., at the commencement of this haul, the Amrum Light was seen, bearing $\mathrm{E}$. by $\mathrm{N}$., and Heligoland Light, bearing S. by W. I was not on deck when the fish were sorted, but some of the smallest were saved for me; they were 6 plaice, 5 in. to $6 \frac{1}{4}$ in. in length; 21 dabs, 2 of them $2 \frac{1}{4}$ in. long, the rest $3 \frac{3}{4}$ in. to $6 \frac{1}{2}$ in. The fish kept for market were :-

7 baskets small plaice.

3 " medium ,

1 " gibbed haddock.

3 " kit

50 pair soles.

21 turbot and brill.

1 latchet, 1 cod.

Fourteenth haul, 8.30 a.m., June 9 th. We steered in to the eastward, to see if there were more soles to be got nearer the land and at $8 \mathrm{a} . \mathrm{m}$. sounded $9 \frac{1}{2}$ fathoms. At this time there were five steam trawlers in sight, one smack, and six German sailing vessels of small size, of a kind called "snibs" by the Grimsby fishermen. There were 60 turbot and brill altogether this haul. I examined 19 brill and 5 turbot. Of the brill, 11 were immature females, the smallest $11 \frac{1}{4}$ in., the largest $13 \frac{1}{2}$ in. in length. The other 8 were males, the smallest $10 \frac{3}{4}$ in., the largest $17 \frac{1}{2}$ in. long, and all mature except one at $11 \frac{1}{4}$ in., which would probably have become ripe this season. Of the whole 19,5 were under 12 in.4 males and 1 female. Of the turbot, 1 at $31 \frac{3}{4}$ in. was a spent female, 1 at $20 \frac{3}{4}$ in. was a mature but not ripe female, 1 at $12 \frac{1}{4}$ in. was an immature female and $2,12 \frac{3}{4}$ in. and $14 \mathrm{in}$., were mature males. The rest of the fish kept for market were:-

$2 \frac{1}{2}$ baskets medium plaice, $12 \frac{1}{2}$ in. to 16 in.

5. " small plaice, $9 \frac{1}{4}$ in. to $12 \frac{1}{2} \mathrm{in}$.

1 basket kit haddock.

$\frac{1}{2}$ " gibbed haddock.

$\frac{1}{2}$ " codling and dabs.

3 large cod.

30 pair of soles. 
The soles in this and other hauls were ripe and spawning. As usual, a lot of small plaice, gurnard, and dabs were thrown overboard. The soles were more plentiful than was usual for a day haul.

Fifteenth haul, 12.30 p.m., June 9 th. Just before this haul we sounded $10 \frac{1}{2}$ fathoms. The fish kept were:-

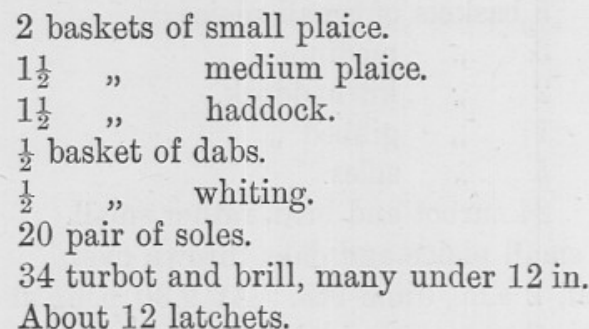

The smallest brill was $9 \frac{1}{4}$ in. long. The smallest dab saved was $9 \frac{1}{2}$ in. long. I was told that the last time the vessel sold her fish the dabs fetched 10s. a box, which is more than the usual price of small plaice: Whiting were saved for the first time this haul, as they do not keep well for many days in the fish-hold.

I examined half a basketful of the stuff thrown overboard. It contained :- 101 male plaice, smallest $6 \frac{1}{8}$ in., largest $10 \frac{1}{4}$ in.

46 female plaice, smallest $6 \frac{1}{8}$ in., largest $9 \frac{3}{4}$ in.

18 male dabs, $6 \frac{1}{2}$ in. to $9 \frac{1}{2}$ in.

17 female dabs, $5 \frac{3}{4}$ in. to 9 in.

7 Trigla gurnardus.

Trigla cuculus.

1 Raia clavata, $11 \frac{1}{4}$ in. across the pectorals.

Sixteenth haul, 8.30 p.m., June 9 th. On this occasion I timed the various stages in the operation of hauling one trawl and shooting the other. The after stopper, which fastens the wire trawl-rope to the quarter of the vessel, to keep it clear of the propeller, was let go at 8.30 p.m. The steam winch was then set in motion and the beam of the trawl was on the rail at 8.40. By 9 o'clock the cod end was hoisted up, the fish emptied out of it and the other trawl shot.

This haul we steered somewhat to the westward, to get away from the small plaice; but the captain said he was afraid we should get away from the soles, too. The catch was not a large one:-

\footnotetext{
$1 \frac{1}{2}$ baskets medium plaice.

1 basket small plaice.

1 " gibbed haddock.

2 baskets kit haddock.

35 turbot and brill.

25 pair of soles.
} 
2 ripe female sprats, 1 hake, and 1 Acanthias vulgaris were also taken. About 2 basketfuls of small plaice, dabs, and gurnard thrown over.

Seventeenth haul, 2.30 a.m., June 10th. During this haul we steered again towards the land, with the result of getting more small plaice and more soles, and fewer haddock. The fish saved were :-

4 baskets medium plaice.

$11 \frac{1}{2}$ „ small plaice.

2 " haddock.

1 basket codling and dabs.

48 pair of soles.

A few brill and turbot, and a dozen latchets. About 20 basketfuls of small plaice, \&c., thrown over.

Eighteenth haul, 8.30 a.m., June 10th. At 8 a.m. Heligoland was plainly visible, bearing S. by W., and about 14 miles distant. The fish saved were :-

4 baskets medium plaice.

$7 \frac{1}{2} \quad$ " small plaice.
$\frac{1}{2} \quad$ gibbed haddock.
$2 \quad$ kit haddock.
14 pair of soles, the smallest $9 \frac{7}{8}$ in.
About 27 turbot and brill.

The smallest plaice was $6 \frac{3}{4}$ in. long. There was a quantity of soft dark-coloured fine sand among the fish.

Nineteenth haul, 2.30 p.m., June 10th. At 1 p.m. Heligoland was bearing S.S.W. The fish were on deck at 2.50 p.m., and at 3.10 many of the small plaice, dabs, \&c., were being shovelled overboard, and many were alive. Those shovelled over towards the end of the work of sorting and gutting are nearly all dead. I counted the sexes in a number of the larger or medium-sized plaice, and found 99 females to 43 males, the largest female being $16 \frac{3}{4}$ in., the largest male $16 \frac{1}{4}$ in. The smallest plaice in the haul was 6 in. long. According to the mate's reckoning, there were only 8 pair of soles; I counted 32 soles, the mate neglecting the slips. The small plaice were very abundant, the other fish saved being:- $\quad 4 \frac{1}{2}$ baskets medium plaice.

13 " small plaice.

1 basket haddock.

1 " dabs and codling, 1 large cod.

14 turbot and brill, 1 small turbot being only $9 \mathrm{in.} \mathrm{long.}$

Twentieth haul, 8.30 p.m., June 10th. We steered to the north and somewhat nearer to the land this haul, in order to find more soles: we 
were out of sight of Heligoland. We sounded $7 \frac{1}{2}$ fathoms some time before $6.45 \mathrm{p} . \mathrm{m}$., and at that time 10 fathoms, the ground being sharp gravelly sand. There were a large number of German "snibs" in sight. These vessels are of shallow draft, only partially decked, and smack rigged. They carry small trawls, only about 20 feet long, which they pull up by hand. They must take a large number of the small plaice, but whether they destroy them or not I do not know. Probably they fish principally for the sake of the soles.

This haul produced more soles and fewer plaice than the previous one, which was taken further to the southward:-

1 basket medium plaice.

6 " small plaice.

33 pairs of soles.

1 turbot 9 in. long, 1 turbot $9 \frac{3}{4}$ in.

Twenty-first haul, 3 a.m., June 11th. As usual in a night haul, soles were taken this time more abundantly: no detailed observations on the fish were made by me. The marketable part of the catch comprised:-

1 basket medium plaice.

5 „ small

2, haddock.

50 pairs of soles.

19 turbot and brill, none large.

3 latchets, a few whiting, dabs, and codling.

Twenty-second haul, 10 a.m., June 11th. This was the last haul: we started at full speed for Grimsby at 10.20 .

At 9 a.m. Heligoland was in sight, bearing S. by W. 15 to 18 miles distant and I counted 25 foreign "snibs" in sight.

This haul there were taken 25 turbot, 8 brill. I examined a number of them, namely, 15 turbot and 3 brill. Of the former 12 were mature males, 6 of them 13 in. long; 2, 14 in.; 1, 19 in., and 3, 20 in. Of the 3 females, one $15 \mathrm{in}$. long was immature, two $22 \mathrm{in}$. long were mature. Of the brill two were mature males $10 \mathrm{in}$. and $14 \frac{1}{2}$ in. long, the third was an immature female $12 \mathrm{in}$. long.

The rest of the fish saved were:-

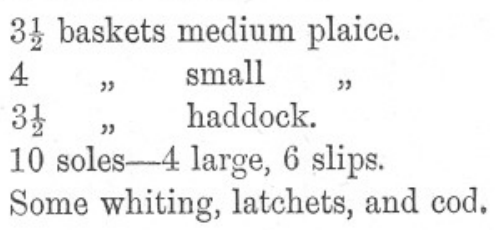

In one haddock's stomach I found Trophonia, whitings, and a dab; in another, brittle stars. 
I landed at Grimsby on the afternoon of June 12th and on June 13th examined at Cleethorpes some of the fish I brought from the steamer on which I made the voyage. Among these were 9 soles, of the size at which they are called slips, that is to say, the smallest soles caught. They were $10 \frac{1}{4}$ to $11 \frac{1}{4}$ in. in length, and all of them were mature males.

I also brought a basket of the refuse from the last haul. It proved to contain :-

105 male plaice, smallest $6 \frac{1}{2}$ in., largest $11 \frac{1}{2}$ in., next largest 10 in.

71 female plaice, smallest $6 \frac{3}{4}$ in., largest $11 \frac{1}{8}$ in., next largest 11 in. and $10 \frac{1}{2}$ in.

31 male dabs, $5 \frac{3}{4}$ in. to $10 \frac{1}{4}$ in.

21 female dabs, 5 in. to $10 \frac{3}{4}$ in.

6 Trigla gurnardus, $9 \frac{1}{2}$ to $11 \frac{1}{2}$ in.

I examined the ovaries of a few of these fish microscopically:

Plaice 8 in. long, ovary small, ova yolkless, no opaque masses.

" 8 in. long, " "

" $8 \frac{1}{4}$ in. " " " "

" $8 \frac{3}{4}$ in. , ",$"$,

" $9 \frac{1}{4}$ in. " ovary small, but opaque masses very distinct and numerous

" $10 \frac{1}{4}$ in. " one or two dead eggs in ovarian tissue.

" $10 \frac{3}{4}$ in. " ovary 2 in. from anterior end, $3 \frac{5}{I^{6}}$ in. from posterior end of ventral fin. No opaque masses.

Plaice $10 \frac{5}{8}$ in. Opaque masses numerous, small, nearly absorbed.

" $11 \mathrm{in}$. Opaque masses and dead yolked eggs very numerous and conspicuous.

Dab $7 \frac{5}{8}$ in. Probably spawned, but ovary small and transparent, no opaque masses or yolked eggs.

" $8 \frac{1}{4}$ in. Ovary $1 \frac{3}{4}$ in. from anterior end, $2 \frac{1}{2}$ in. from posterior end of ventral fin. Almost certainly recently spawned, some partially yolked eggs present, but not dark and opaque as in the plaice.

" $7 \frac{5}{5}$ in. Ovary half as long as the ventral fin, red in colour, contained some half-ripe eggs, but not dead yolked eggs as in the plaice.

I must postpone the discussion of these observations until a future occasion. 